\title{
Monitoring of Pesticides and Polycyclic Aromatic Hydrocarbons in Water from Paraíba do Sul River, Brazil
}

\author{
Débora de A. Azevedo*, Elaine Gerchon and Ederson O. dos Reis \\ Instituto de Química, Universidade Federal do Rio de Janeiro, Ilha do Fundão, CT, Bl. A, s.603, \\ 21949-900 Rio de Janeiro - RJ, Brazil
}

\begin{abstract}
Estudou-se a qualidade da água do Rio Paraíba do Sul através da determinação das concentrações de alguns poluentes orgânicos prioritários, a saber, hidrocarbonetos policíclicos aromáticos (HPAs) e pesticidas. Duas cidades foram selecionadas, Resende e Campos dos Goytacazes, três sítios em cada, por apresentarem atividades industriais e agrícolas. O estudo foi desenvolvido entre Julho de 2001 a Março de 2002. O método envolveu a extração de $200 \mathrm{~mL}$ de amostra por extração em fase sólida utilizando cartucho polimérico OASIS, seguido pela análise por cromatografia gasosa acoplada a espectrometria de massas (CG/EM). A recuperação e o desvio padrão para amostras de água real não poluída dopada com padrões de pesticidas foi de $82-119 \%$ e menos de $20 \%$, respectivamente. Para os HPAs, a recuperação e o desvio padrão foram de 56-78\% e menos de 18\%, respectivamente, com exceção do acenaftileno, $23 \%$ e 2,7\%. Atrazina foi detectada em uma concentração média de $0,231 \mu \mathrm{g} \mathrm{L}^{-1} \mathrm{em}$ dois sítios em Campos dos Goytacazes, nas proximidades de usina e plantações de cana de açúcar, enquanto em Resende não foi detectada. Irgarol foi observado no centro de Campos de Goytacazes a uma concentração de $0,138 \mu \mathrm{g} \mathrm{L}^{-1}$, uma área com atividades de barcos de pequeno porte. Benzo[a]pireno foi detectado em Resende a uma concentração de $0,255 \mu \mathrm{g} \mathrm{L}^{-1}$, próximo a rodovia Presidente Dutra. HPAs não foram detectados nas amostras de água de Campos dos Goytacazes.
\end{abstract}

The Paraíba do Sul River, in the State of Rio de Janeiro, was studied for its water quality, by determining the levels of selected polycyclic aromatic hydrocarbons (PAHs) and pesticides from six sites in two cities, Resende and Campos dos Goytacazes, as they have industrial and agricultural activities. This study was carried out between July 2001 and March 2002. The method involved 200 $\mathrm{mL}$ samples taken by off-line, solid phase extraction by OASIS polymeric cartridges followed by gas chromatography-mass spectrometry (GC-MS). Recoveries and standard deviation of pesticides in non polluted real water sample spiked with a standard mixture were $82-119 \%$ and less then $20 \%$. For PAH, recoveries and standard deviation were $56-78 \%$ and less then $18 \%$, respectively, with exception to acenaphthylene, $23 \%$ and $2.7 \%$. Atrazine was detected in the average concentration of $0.231 \mu \mathrm{g} \mathrm{L}^{-1}$ in two sites in Campos dos Goytacazes, near the sugar-cane power plants and plantations area, while no detection was observed in Resende. Irgarol was observed in Campos dos Goytacazes downtown at $0.138 \mu \mathrm{g} \mathrm{L}^{-1}$, an area of small boating activities. Benzo[a]pyrene was detected at $0.255 \mu \mathrm{g} \mathrm{L}^{-1}$ in Resende, near the Presidente Dutra highway. PAHs were not detected in the water samples from Campos dos Goytacazes.

Keywords: atrazine, water, PAHs, pesticides, GC-MS

\section{Introduction}

National and international pressure is growing for water quality improvement and better management. The need for monitoring some important groups of dangerous organic pollutants, such as polyaromatic hydrocarbons (PAHs), pesticides, phenolic compounds, alkyl and aromatic sulfonates in surface waters is essential for

\footnotetext{
*e-mail: debora@iq.ufrj.br
}

achieving good water-quality objectives. The European list of the priority organic compounds to be monitored from discharges is the Directive EC 76/464 ${ }^{1}$ while Brazilian regulations are CONAMA no. 20 from the Environmental Ministry and regulation no. 1469 from the Health Ministry. Regulations for drinking water are well defined in North America with given analytical procedures, whereas in Europe the regulation for each pesticide is set at $0.1 \mu \mathrm{g} \mathrm{L}^{-1}$ and for polyaromatic hydrocarbons, total of 6 compounds is set at $0.2 \mu \mathrm{g} \mathrm{L}^{-1} .2,3$ 
Atrazine was introduced in the 1950s, and since that has become a commonplace in agricultural and forestry applications. For instance, atrazine is used to control annual grasses and broad-leaved weeds in selected vegetable and cereal crops, vines, sugar cane, grassland, fruit orchards, citrus groves, and forestry. It is the most widely used herbicide in the world, with between 70,000 and 90,000 tons applied per year. It is one of the most effective and inexpensive herbicides in the world and is consequently used more frequently than any other herbicide. In recent years, concerns have been raised regarding its persistence within the environment and entry into groundwater and the aquatic environment. Atrazine is most effective in wet soils and is therefore usually applied after significant winter rain when soils are at field capacity. ${ }^{4}$ Banning atrazine completely would cost \$240 million, with no improvement in water quality. Banning all triazines would improve water quality, but it would cost nearly $\$ 740$ million. The most effective policies appear to be atrazine restrictions based on federal health limits of $3 \mu \mathrm{g} \mathrm{L}^{-1}$ or $100 \mu \mathrm{g} \mathrm{L}^{-1}$, water quality was greatly improved at a cost of between $\$ 160$ $\$ 230$ million. $^{5}$

Polycyclic aromatic hydrocarbons are widespread contaminants throughout the environment arising mainly from anthropogenic sources such as the combustion from fossil fuels and the direct release of oil and oil products. These widespread environmental contaminants have been intensively studied owing to their mutagenic and carcinogenic properties. Some of the PAHs are classified as priority pollutants by both the US EPA and the European Community. ${ }^{6}$

This study aims to carry out a survey of selected organic micropollutants in the water samples from Paraíba do Sul River, focusing on three sites each in two important cities in the State of Rio de Janeiro, Resende and Campos dos Goytacazes, that suffers industrial and agricultural impact, and also to carry out a partial validation of the used methodology.

\section{Experimental}

\section{Sampling sites}

The city of Campos dos Goytacazes (latitude $21^{\circ} 45^{\prime} 15^{\prime}$ 'S and longitude $41^{\circ} 19^{\prime} 28^{\prime \prime} \mathrm{W}$ ) with about 398,547 inhabitants, is the most important city in the northern part of the state of Rio de Janeiro. It is basically an agricultural area, in which the sugar cane plantation is the main economic activity with sugar/alcohol power plants.

The city of Resende (around latitude 22 $28^{\prime}$ 'S and longitude $44^{\circ} 27^{\prime} \mathrm{W}$ ) with about 120,000 inhabitants and an area of $407 \mathrm{~km}^{2}$, is an important city in the southern part of the state of Rio de Janeiro. It is an industrial area with agricultural (tomato, corn, rice, bean) and ecological activities. Some industries in this area are Clariant, Volkswagen Brazil, Norvartis and Cyanamid Brazil.

Three sites were chosen in each city for sampling: sites 1 and 4, just before downtown; 2 and 5, downtown the cities; 3 and 6 , after passing through downtown. The unpolluted river water sample was sampled from an ecological site, Lumiar, Nova Friburgo (RJ; latitude $22^{\circ} 16^{\prime} 55^{\prime \prime}$ S and longitude $42^{\circ} 31^{\prime} 52^{\prime \prime} \mathrm{W}$ ). Figure 1 shows the Paraíba do Sul River map, with the two cities in study.



Figure 1. Map from the selected sampling sites.

\section{Chemicals}

The standards used were $98-99 \%$ pure. It was studied 10 compounds (Table 1). Pesticides standards were obtained from Promochem (Wesel, Germany) and Riedelde Haën (Seelze, Germany). Irgarol was from Ciba-Geigy (Barcelona, Spain). Polycyclic aromatic hydrocarbons standard as Phenanthrene, Fluoranthene, Pyrene, Chrysene and Benzo[a]pyrene are from Sigma/Aldrich (USA). Stock solutions of $1000 \mu \mathrm{g} \mathrm{mL}^{-1}$ were prepared by weighing 10

Table 1. Retention time, diagnostic $\mathrm{m} / \mathrm{z}$ ions, calibration equation and coefficients of correlation $\left(\mathrm{R}^{2}\right)$ in SIM mode of organic compounds using SPE followed by GC/MS

\begin{tabular}{lllll}
\hline Compounds & $\mathrm{t}_{\mathrm{R}}$ & $\mathrm{m} / z$ & Calibration equation & $\mathrm{R}^{2}$ \\
\hline Simazine & 24.6 & $186 / 201$ & $Y=117951 X-3430$ & 0.999 \\
Atrazine & 24.8 & $173 / 200$ & $Y=203607 X-45917$ & 0.994 \\
Alachlor & 27.7 & $160 / 188$ & $Y=58162 X+659$ & 0.999 \\
Irgarol & 30.4 & $182 / 238$ & $Y=11767 X-2048$ & 0.999 \\
Acenaphthylene & 18.7 & 152 & $Y=723244 X-4774$ & 0.999 \\
Phenanthrene & 25.5 & 178 & $Y=886338 X-184998$ & 0.993 \\
Fluoranthene & 30.5 & 202 & $Y=484806 X+11008$ & 0.995 \\
Pyrene & 31.3 & 202 & $Y=802262 X-13653$ & 0.994 \\
Chrysene & 36.6 & 228 & $Y=431547 X-10253$ & 0.994 \\
Benzo[a]pyrene & 41.7 & 252 & $Y=188424 X-6306$ & 0.997 \\
\hline
\end{tabular}


$\mathrm{mg}$ of each of the solutes and dissolving them in $10 \mathrm{~mL}$ of chromatographic-grade dichloromethane or acetonitrile (TediaBrazil, Rio de Janeiro). They were then stored at $-20{ }^{\circ} \mathrm{C}$. Dichloromethane and acetonitrile ABSOLV (chromatographic grade) were from TediaBrazil, acetic acid was purchased from Grupo Química (Rio de Janeiro, Brazil).

\section{Sampling}

The samples were collected at July and October/2001 and March/2002. All the water samples were sampled at $20 \mathrm{~cm}$ depth using $1 \mathrm{~L}$ precleaned amber glass bottles (avoiding the surface micro-layer). Samples were acidified with acetic acid to $\mathrm{pH} 4.0$, filtered through 1.2 and $0.45 \mu \mathrm{m}$ glass fiber filters in order to remove suspended particles and kept at $4{ }^{\circ} \mathrm{C}$ in the dark until analysis.

\section{SPE extractions}

The OASIS cartridges (60 mg, Waters, USA) were washed sequentially with $6 \mathrm{~mL}$ of dichloromethane, $6 \mathrm{~mL}$ of acetonitrile and $6 \mathrm{~mL}$ of water. A 200-mL aliquot of sample was passed though the cartridge and then washed with $1 \mathrm{~mL}$ of water. Water residues from cartridges were eliminated by $30 \mathrm{~min}$ vacuum. Elution was carried out with $2.5 \mathrm{~mL}$ of acetonitrile-dichloromethane (1:1) followed by $3.2 \mathrm{~mL}$ of dichloromethane. ${ }^{7}$

The C18 (200 mg, PR-COLA) and the Bond-Elut Certify (130 mg, Varian, PN: 1211-3054) cartridges were washed sequentially with $6 \mathrm{~mL}$ of methanol and $6 \mathrm{~mL}$ of bidistilled water. A $200 \mathrm{~mL}$ aliquot of sample was passed though the cartridge and then washed with $1 \mathrm{~mL}$ of water. Water residues from cartridges were eliminated by $30 \mathrm{~min}$ vacuum. Elution was carried out with $6 \mathrm{~mL}$ of methanol for the $\mathrm{C} 18$ cartridges and with $2 \mathrm{~mL}$ dichlorometane/ isopropanol (8:2) with $2 \%$ ammonium hydroxide solution (make fresh daily) for the Bond-Elut Certify.

Evaporation of the solvents was performed under a stream of nitrogen. The final sample volumes were $200 \mu \mathrm{L}$.

\section{GC/MS conditions}

Gas chromatography-mass spectrometry analysis were performed in a Hewlett Packard 5890 gas chromatography coupled to a Hewlett Packard 5972 MSD Instrument utilizing helium as carrier gas and the following conditions: fused silica column DB-5 (J \& W, 30 m X 0.25 $\left.\mathrm{mm}, \mathrm{d}_{\mathrm{f}}=0.25 \mu \mathrm{m}\right), 60^{\circ} \mathrm{C}$ for $2 \mathrm{~min}$ to $300{ }^{\circ} \mathrm{C}$ at $6^{\circ} \mathrm{C} \mathrm{min}{ }^{-1}$, splitless injection mode (time of $1 \mathrm{~min}$ ), temperature of injector was set at $280^{\circ} \mathrm{C}$. Electron impact at $70 \mathrm{eV}$ was used. All samples were analysed in Single Ion Monitoring (SIM) mode for quantification purposes of the compounds, Figure 2 (major ions corresponding to the typical fragments of the compounds were selected, Table 1).

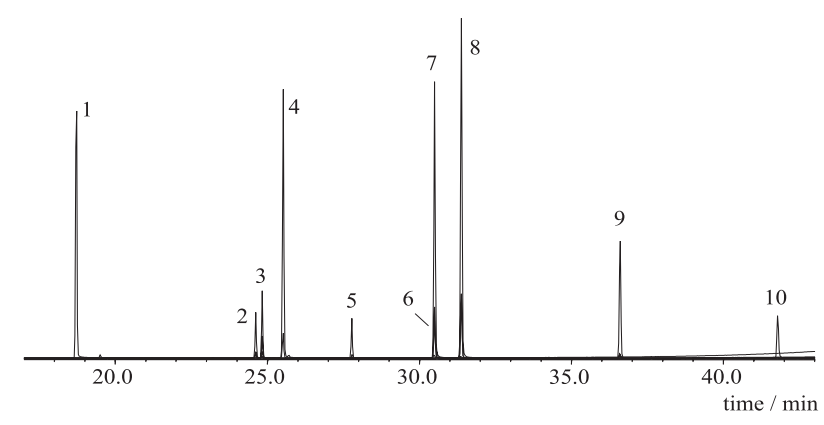

Figure 2. Overlaid mass fragmentograms in SIM mode from the standard compounds in study at $0.7 \mu \mathrm{g} \mathrm{L}^{-1}$. (1) Acenaphthylene $(\mathrm{m} / z \mathrm{z} 2 \mathrm{z})$, (2) Simazine $(\mathrm{m} / \mathrm{z}, 201)$, (3) Atrazine $(\mathrm{m} / \mathrm{z}, 200)$, (4) Phenanthrene ( $\mathrm{m} / \mathrm{z}$ 178), (5) Alachor ( $\mathrm{m} / \mathrm{z}, 160)$, (6) Irgarol $(\mathrm{m} / \mathrm{z}$ 182), (7) Fluoranthene ( $\mathrm{m} / \mathrm{z}$ 202), (8) Pyrene ( $\mathrm{m} / \mathrm{z}, 202)$, (9) Chrysene ( $\mathrm{m} / \mathrm{z}, 228),(10)$ Benzo[a]pyrene $(\mathrm{m} / \mathrm{z}, 252)$.

\section{Recoveries}

Recoveries obtained with distilled water samples spiked with standard compounds were tested in different conditions. Three different SPE cartridges were evaluated: C18 (PR-COLA, Brazil), Bond-Elut Certify (Varian, Harbor City, CA, USA), OASIS (Waters). The water $\mathrm{pH}$ was also evaluated; water sample with and without addition of acetic acid ( $\mathrm{pH} 4.0)$.

Unpolluted river water samples were also used for OASIS SPE cartridge. The compounds were spiked in 200 $\mathrm{mL}$ of water to give a final concentration of $1.0 \mu \mathrm{g} \mathrm{L}^{-1}$ and subsequently the water was acidified at lower $\mathrm{pH}(\mathrm{pH} 4.0)$. Immediately after this operation, the water samples were extracted.

The recovery were determined by comparison of peak areas from water samples spiked with known amount of organic pollutants $\left(1.0 \mu \mathrm{g} \mathrm{L}^{-1}\right)$, processed according to the described method versus non-extracted pure standards which represent $100 \%$ recovery.

External calibration was used to the quantification of the extract after SPE with the standard mixture. The calibration equations for the different compounds were constructed and were linear $\left(\mathrm{R}^{2}>0.99\right)$ over the range 0.05-1.0 $\mu \mathrm{g} \mathrm{L}^{-1}$. The quantification of the water was achieved using SIM with the ions indicated in Table 1. The limits of detection (LODs) were calculated by using a signal-to-noise ratio of 3 (the ratio between the peak intensity under SIM conditions and the intensity of the noise was used) and are presented in Table 2. Recoveries are presented in Table 3. 
Table 2. Limits of detection (LOD) in $\mu \mathrm{g} \mathrm{L}^{-1}$ of the standard compounds in study with different cartridges tested: C18 (PR-Cola), Bond-Elut Certify (Varian) and Oasis (Waters). Unpolluted river water spiked with $1.0 \mu \mathrm{g} \mathrm{L}^{-1}$ of organic pollutants

\begin{tabular}{llll}
\hline Compounds & $\mathrm{C} 18$ & Bond-Elut & Oasis \\
\hline Simazine & 0.02 & 0.04 & 0.0005 \\
Atrazine & 0.016 & 0.003 & 0.0005 \\
Alachlor & 0.0006 & 0.0006 & 0.001 \\
Irgarol & 0.004 & - & 0.0002 \\
Acenaphthylene & 0.20 & 0.04 & 0.0009 \\
Phenanthrene & 0.0004 & 0.0001 & 0.0003 \\
Fluoranthene & 0.002 & 0.0001 & 0.0003 \\
Pyrene & 0.002 & 0.0001 & 0.0002 \\
Chrysene & 0.0007 & 0.0004 & 0.0002 \\
Benzo[a]pyrene & 0.004 & 0.004 & 0.001 \\
\hline
\end{tabular}

\section{Limits of detection for OASIS cartridges}

A calibration curve consisted of six concentration points from $0.01,0.025,0.05,0.10,0.20$ to $0.50 \mu \mathrm{g}$ of organic pollutants per $1 \mathrm{~L}$ of unpolluted river water. These spiked water samples were passed thought the OASIS cartridges. The calibration equations for the different compounds were constructed and were linear $\left(\mathrm{R}^{2}>0.99\right)$ over the range $0.01-0.5 \mu \mathrm{g} \mathrm{L}^{-1}$. The limits of detection (LODs) were calculated by using a signal-to-noise ratio of 3 and the constructed calibration curve (Table 4).

Table 3. Mean recovery, $\bar{x}(\%)$, confidence limits, CL (\%), coefficient of variation, CV (\%), standard deviation, SD (\%), for replicates $(\mathrm{n}=4 ; 3$ degree of freedom), using Student $t$-test $\left(95 \% ; \mathrm{t}_{\mathrm{tab}}=3.182\right)$. Spiked sample at $1.0 \mu \mathrm{g} \mathrm{L}^{-1}$. River water volume: $200 \mathrm{~mL}$

\begin{tabular}{|c|c|c|c|c|c|c|c|}
\hline Atrazine & $\bar{x} \pm \mathrm{CL}(\%)$ & $\mathrm{CV}(\%)$ & SD $(\%)$ & Fluoranthene & $\bar{x} \pm \mathrm{CL}(\%)$ & $\mathrm{CV}(\%)$ & SD $(\%)$ \\
\hline Oasis d & $117.2 \pm 12.3$ & 6.6 & 7.7 & Oasis d & $105.2 \pm 12.3$ & 7.3 & 7.7 \\
\hline Oasis $\mathrm{d} / \mathrm{pH}=4$ & $94.9 \pm 24.4$ & 16.1 & 15.3 & Oasis $\mathrm{d} / \mathrm{pH}=4$ & $87.0 \pm 25.5$ & 18.4 & 16.1 \\
\hline Oasis $\mathrm{r} \mathbf{p H}=4$ & $106.3 \pm 19.7$ & 11.7 & 12.4 & Oasis $\mathrm{r} \mathbf{p H}=4$ & $78.3 \pm 22.4$ & 18.0 & 14.1 \\
\hline $\mathrm{C} 18 \mathrm{~d} / \mathrm{pH}=4$ & $80.6 \pm 3.3$ & 2.6 & 2.1 & $\mathrm{C} 18 \mathrm{~d} / \mathrm{pH}=4$ & $71.4 \pm 20.8$ & 18.3 & 13.1 \\
\hline $\mathrm{C} 18 \mathrm{~d}$ & $91.1 \pm 13.6$ & 9.4 & 8.5 & $\mathrm{C} 18 \mathrm{~d}$ & $44.2 \pm 18.2$ & 25.9 & 11.4 \\
\hline BE d $(n=2)$ & $73.8 \pm 49.4$ & 42.1 & 31.0 & $\operatorname{BE} d(n=2)$ & $50.2 \pm 35.3$ & 44.3 & 22.2 \\
\hline $\mathrm{BE} \mathrm{d} / \mathrm{pH}=4$ & $87.1 \pm 10.9$ & 7.9 & 6.9 & $\mathrm{BE} \mathrm{d} / \mathrm{pH}=4$ & $47.5 \pm 11.6$ & 15.4 & 7.3 \\
\hline \multicolumn{4}{|l|}{ Simazine } & \multicolumn{4}{|l|}{ Pyrene } \\
\hline Oasis d & $101.8 \pm 15.4$ & 9.5 & 9.7 & Oasis d. & $72.4 \pm 16.4$ & 14.3 & 10.3 \\
\hline Oasis $\mathrm{d} / \mathrm{pH}=4$ & $95.2 \pm 19.0$ & 12.5 & 11.9 & Oasis $\mathrm{d} / \mathrm{pH}=4$ & $84.8 \pm 25.5$ & 18.4 & 16.1 \\
\hline Oasis $\mathrm{r} \mathbf{p H}=4$ & $81.6 \pm 16.6$ & 12.8 & 10.4 & Oasis $\mathrm{r} \mathbf{p H}=4$ & $72.8 \pm 13.0$ & 11.2 & 8.1 \\
\hline $\mathrm{C} 18 \mathrm{~d} / \mathrm{pH}=4$ & $91.6 \pm 19.1$ & 13.1 & 12.0 & $\mathrm{C} 18 \mathrm{~d} / \mathrm{pH}=4$ & $34.7 \pm 4.3$ & 7.8 & 2.7 \\
\hline C18 d & $80.7 \pm 22.4$ & 17.5 & 14.1 & $\mathrm{C} 18 \mathrm{~d}$ & $51.6 \pm 14.3$ & 17.4 & 8.9 \\
\hline BE d $(n=2)$ & $71.4 \pm 43.5$ & 38.3 & 27.4 & $\mathrm{BE} d(\mathrm{n}=2)$ & $62.2 \pm 39.2$ & 39.6 & 24.6 \\
\hline $\mathrm{BE} \mathrm{d} / \mathrm{pH}=4$ & $24.8 \pm 7.1$ & 17.9 & 4.5 & $\mathrm{BE} \mathrm{d} / \mathrm{pH}=4$ & $74.7 \pm 36.7$ & 30.8 & 23.0 \\
\hline \multicolumn{4}{|l|}{ Irgarol } & \multicolumn{4}{|l|}{ Chrysene } \\
\hline Oasis d & $112.1 \pm 33.1$ & 18.5 & 20.8 & Oasis d & $104.7 \pm 38.1$ & 22.9 & 24.0 \\
\hline Oasis $\mathrm{d} / \mathrm{pH}=4$ & $98.6 \pm 32.8$ & 20.9 & 20.6 & Oasis $\mathrm{d} / \mathrm{pH}=4$ & $84.2 \pm 27.0$ & 20.2 & 17.0 \\
\hline Oasis $\mathrm{r} \mathbf{p H}=4$ & $119.4 \pm 25.6$ & 13.5 & 16.1 & Oasis r pH=4 & $77.7 \pm 5.1$ & 4.1 & 3.2 \\
\hline $\mathrm{C} 18 \mathrm{~d} / \mathrm{pH}=4$ & $47.9 \pm 16.9$ & 22.2 & 10.6 & $\mathrm{C} 18 \mathrm{~d} / \mathrm{pH}=4$ & $12.4 \pm 2.0$ & 10.2 & 1.3 \\
\hline C18 d & $88.9 \pm 20.7$ & 14.6 & 13.0 & $\mathrm{C} 18 \mathrm{~d}$ & $25.7 \pm 8.4$ & 20.6 & 5.3 \\
\hline BE d $(n=2)$ & $\mathrm{nd}$ & $\mathrm{nd}$ & $\mathrm{nd}$ & BE d. $(n=2)$ & $13.7 \pm 4.6$ & 20.9 & 2.9 \\
\hline $\mathrm{BE} \mathrm{d} / \mathrm{pH}=4$ & $\mathrm{nd}$ & $\mathrm{nd}$ & nd & $\mathrm{BE} \mathrm{d} / \mathrm{pH}=4$ & $32.5 \pm 7.6$ & 14.6 & 4.8 \\
\hline \multicolumn{4}{|l|}{ Alachlor } & \multicolumn{4}{|l|}{ Benzo[a]pyrene } \\
\hline Oasis d & $84.4 \pm 43.0$ & 32.2 & 27.01 & Oasis d & $76.4 \pm 11.4$ & 9.4 & 7.2 \\
\hline Oasis $\mathrm{d} / \mathrm{pH}=4$ & $99.4 \pm 19.0$ & 12.5 & 11.9 & Oasis $\mathrm{d} / \mathrm{pH}=4$ & $108.2 \pm 14.1$ & 8.2 & 8.8 \\
\hline Oasis r pH=4 & $117.0 \pm 32.5$ & 17.4 & 20.4 & Oasis $r$ pH=4 & $55.6 \pm 5.0$ & 5.7 & 3.2 \\
\hline $\mathrm{C} 18 \mathrm{~d} / \mathrm{pH}=4$ & $81.0 \pm 31.2$ & 24.2 & 19.6 & $\mathrm{C} 18 \mathrm{~d} / \mathrm{pH}=4$ & $31.0 \pm 16.9$ & 34.3 & 10.6 \\
\hline C18 d & $39.9 \pm 25.8$ & 40.6 & 16.2 & $\mathrm{C} 18 \mathrm{~d}$ & $14.1 \pm 2.5$ & 11.2 & 1.6 \\
\hline BE d $(n=2)$ & $146.8 \pm 71.2$ & 30.5 & 44.7 & $\mathrm{BE} d(\mathrm{n}=2)$ & $\mathrm{nd}$ & $\mathrm{nd}$ & $\mathrm{nd}$ \\
\hline $\mathrm{BE} \mathrm{d} / \mathrm{pH}=4$ & $55.8 \pm 20.6$ & 23.2 & 13.0 & $\mathrm{BE} \mathrm{d} / \mathrm{pH}=4$ & $\mathrm{nd}$ & nd & $\mathrm{nd}$ \\
\hline \multicolumn{4}{|l|}{ Phenanthrene } & \multicolumn{4}{|l|}{ Acenaphthylene } \\
\hline Oasis d. & $77.1 \pm 34.1$ & 27.8 & 21.4 & Oasis d & $41.3 \pm 31.2$ & 47.5 & 19.6 \\
\hline Oasis $\mathrm{d} / \mathrm{pH}=4$ & $69.9 \pm 36.7$ & 33.0 & 23.1 & Oasis $\mathrm{d} / \mathrm{pH}=4$ & $26.9 \pm 23.7$ & 55.7 & 14.9 \\
\hline Oasis r pH=4 (n=3) & $62.5 \pm 12.8$ & 12.8 & 8.0 & Oasis r pH=4 (n=2) & $23.2 \pm 4.2$ & 11.5 & 2.7 \\
\hline $\mathrm{C} 18 \mathrm{~d} / \mathrm{pH}=4$ & $48.2 \pm 36.7$ & 33.0 & 27.3 & $\mathrm{C} 18 \mathrm{~d} / \mathrm{pH}=4$ & $8.5 \pm 9.7$ & 71.7 & 6.1 \\
\hline C18 d & $46.2 \pm 3.7$ & 5.0 & 2.3 & $\mathrm{C} 18 \mathrm{~d}$ & $8.6 \pm 3.2$ & 23.5 & 2.0 \\
\hline $\mathrm{BE} d(\mathrm{n}=2)$ & $50.2 \pm 26.5$ & 38.4 & 16.6 & $\mathrm{BE} d(\mathrm{n}=2)$ & $3.5 \pm 3.2$ & 23.5 & 2.0 \\
\hline $\mathrm{BE} \mathrm{d} / \mathrm{pH}=4$ & $60.9 \pm 46.6$ & 48.1 & 29.3 & $\mathrm{BE} \mathrm{d} / \mathrm{pH}=4$ & $4.9 \pm 9.7$ & 71.7 & 6.1 \\
\hline
\end{tabular}

$\mathrm{d}=$ distilled water; $\mathrm{r}=$ unpolluted river water; in bold $=$ the conditions used with the real water samples. 
Table 4. Limits of detection (LOD) in $\mu \mathrm{g} \mathrm{L}^{-1}$, calibration equation and coefficients of correlation $\left(\mathrm{R}^{2}\right)$ in SIM mode of the standard compounds using OASIS cartridges. Unpolluted river water spiked with organic pollutants at $0.01,0.025,0.05,0.10,0.20$ and $0.50 \mu \mathrm{g} \mathrm{L}^{-1}$

\begin{tabular}{llll}
\hline Compounds & LODs & Calibration equation & $\mathrm{R}^{2}$ \\
\hline Simazine & 0.01 & $Y=194858 X+1950$ & 0.9968 \\
Atrazine & 0.008 & $Y=285362 X-1508.8$ & 0.9996 \\
Irgarol & 0.003 & $Y=361595 X-274$ & 0.9985 \\
Acenaphthylene & 0.0005 & $Y=370727 X+597$ & 0.999 \\
Phenanthrene & 0.01 & $Y=864858 X+7159$ & 0.9991 \\
Fluoranthene & 0.005 & $Y=1000000 X-4485.4$ & 0.9995 \\
Pyrene & 0.006 & $Y=1000000 X-5442.4$ & 0.9996 \\
Chrysene & 0.025 & $Y=514641 X+6775$ & 0.9992 \\
Benzo[a]pyrene & 0.025 & $Y=174736 X+1269$ & 0.9965 \\
\hline
\end{tabular}

\section{Quantification}

External standard calibration was used for quantification of the extracts. Calibration graphs for SIM mode was plotted using 4-6 points in the concentration $0.05,0.10,0.25,0.5,0.75$ and $1 \mathrm{mg} \mathrm{mL}^{-1}$. Calibration equations obtained in SIM mode and $\mathrm{R}^{2}$ values are presented in Table 1 for GC/MS.

\section{Results and Discussion}

\section{Parcial validation}

Data obtained with standard compounds are presented in Table 3. Recovery (\%), confidence limits (CL, \%), coefficient of variation $(\mathrm{CV}, \%)$, standard deviation (SD, \%), for replicates ( $n=4 ; 3$ degree of freedom), using Student $t$-test $\left(95 \% ; \mathrm{t}_{\mathrm{tab}}=3.182\right)$ were determined. These parameters were well within the acceptance criteria of the accuracy of $70-130 \%$ and precision of $30 \%$ for organic compounds at trace level in water samples, according to the US-EPA methods general characteristics. ${ }^{3}$

The calibration curves constructed were linear over the range of interest. The correlation coefficients were in all cases higher than 0.99 , indicating good performance of the chromatographic method (Table 1). Recoveries with OASIS cartridges for real water samples were around $82-119 \%$ and standard deviation were no more than 20 for pesticides standards and $56-78 \%$ and $18 \%$ for polycyclic aromatic hydrocarbons, respectively. Detection limits (Table 2) were in the range of $0.0002-0.001 \mu \mathrm{g} \mathrm{L}^{-1}$ obtained for distilled water spiked with standard compounds and percolated through the cartridges (far below $0.1 \mu \mathrm{g} \mathrm{L}^{-1}$ ) being good enough for trace levels determination, taking into account that $200 \mathrm{~mL}$ of water were percolated through the cartridges. Low recovery value was observed for acenaphthylene, $23 \%$ as it is a volatile compound and it is lost at the evaporation steep.

The choice for working with OASIS cartridges was based on the recoveries data obtained also with the other tested cartridges. Recoveries and standard deviation for distilled water spiked with the standard mixture and with C18 cartridges were $40-91 \%(\mathrm{SD}=16 \%)$ for pesticides and $14-46 \%$ (11\%) for PAH, while in $\mathrm{pH} 4.0$ were $58-92 \%$ and $20 \%$ for pesticides and $12-71 \%$ and $27 \%$ for PAH (Table 3). Recoveries for Bond-Elut Certify were from not detected to $147 \%$ ( $\mathrm{SD}=45 \%$ ) for pesticides and nd to $62 \%$ (25\%) for PAH without acetic acid addition and from nd to $87 \%$ (13\%) for pesticides and nd to $75 \%$ (29\%) for PAH in $\mathrm{pH}$ 4.0. The data for Oasis cartridges and distilled water samples spiked with standard mixture were $84-117 \%$ (27\%) for pesticides and $72-105 \%$ (24\%) for PAH and 95-99\% (21\%) for pesticides and $84-105 \%$ (25\%) for PAH in $\mathrm{pH} 4.0$.

It is easy to observe that worse results were obtained with Bond-Elut Certify in the conditions tested. The C18 cartridges generated worse results mainly to PAH. Oasis cartridges presented better results to both class of studied compounds: pesticides and $\mathrm{PAH}$, as we were looking for a SFE cartridges that would permit to analyse both class of compounds. Data with real water sample spiked with the standard mixture showed a reduction in the recoveries values, as would be expected, although still being the better results.

Detection limits of polycyclic aromatic hydrocarbons are in the $0.010 \mu \mathrm{g} \mathrm{L}^{-1}$ range. ${ }^{1}$ In this study we observed values in the range 0.0005 up to $0.025 \mu \mathrm{g} \mathrm{L}^{-1}$ (Table 4) when unpolluted river water samples spiked with the standard mixture at different concentrations were analysed. The pesticides gave detection limits in the range $0.003-0.01 \mu \mathrm{g} \mathrm{L}^{-1}$, below the observed values in a previous paper. $^{7}$

\section{Application to a case study}

Water samples from the Paraíba do Sul River were analyzed following the proposed method in six sites from two cities, in three distinct dates. The analytical protocol was applied to the analysis of real environmental samples. Analytes monitored in this study were chosen because they are commonly detected in surface waters and they are on the priority lists of the Brazilian Environmental Ministry (CONAMA no. 20/1986) and Health Ministry (regulation no. 1469/2000) and also of the United State Environmental Protection Agency (US-EPA) and European Community (e.g., Directive 76/464/EEC). 


\section{Triazines}

Highest reported concentrations of atrazine are associated with the first rainfall after application. The level of atrazine in river water varies seasonally with the highest concentrations found in the spring and summer months. The impact of atrazine on fish physiology occurs at concentrations as low as $3 \mu \mathrm{g} \mathrm{L}^{-1}$. Atrazine has been detected in drinking water reservoirs up to $88.4 \mu \mathrm{g} \mathrm{L}^{-1}$, and in rivers up to $100 \mu \mathrm{g} \mathrm{L}^{-1}$.

Atrazine showed a rather constant concentration over time in two sites in Campos dos Goytacazes, in a average concentration of $0.231 \mu \mathrm{g} \mathrm{L}^{-1}$. These sites are near the sugarcane power plants and plantations area. No detection was observed in downtown of Campos dos Goytacazes and in Resende. Figure 3 presents summaries of atrazine concentrations found in freshwater bodies around the world and in Campos dos Goytacazes, this work.

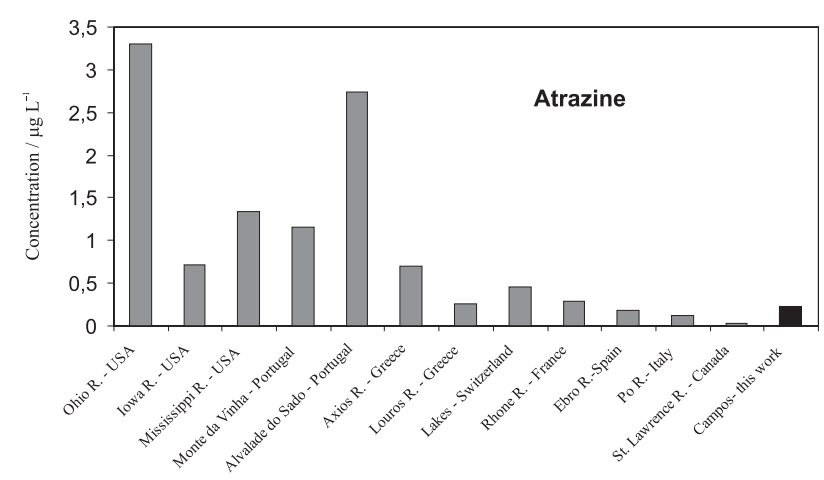

Figure 3. Reported values for atrazine concentrations in water bodies $\left(\mu \mathrm{g} \mathrm{L}^{-1}\right)$ around the world and in this study.

Irgarol, the herbicide 2-(methylthio)-4-(tertbuthylamino)-6-(cyclopropylamino)-s-triazine (tradename Irgarol 1051) was also detected. Irgarol 1051 is effective mostly against freshwater and seawater algae and less against animal organisms. Some studies showed that the substance is very toxic to all microalgae tested; $\mathrm{EC}_{50}$ values range from 0.45 to $2.12 \mathrm{mg} \mathrm{L}^{-1}{ }^{8}$ This compound is used in antifouling paints as a biocide agent. The herbicide is added in paints in order to inhibit the primary growth of fouling organisms such as algal slimes and seaweeds.9,10 Data are available concerning Irgarol contamination of aquatic environment. Studies had been undertaken in Côte $\mathrm{d}^{\prime}$ Azur, ${ }^{10}$ the southern coastal of the U.K., ${ }^{11}$ Lake Geneva, ${ }^{8}$ seawater from Mediterranean Spanish Coast ${ }^{9,10}$ and river and coastal water from Portugal. ${ }^{7}$ Irgarol are added to ship/ boat paints to prevent fouling and diffuse into the surrounding waters and contaminate environments.

The observed concentration of Irgarol in downtown of Campos dos Goytacazes water $\left(138 \mathrm{ng} \mathrm{L}^{-1}\right)$ was only three times lower than the lowest EC50 reported for algae (450 ng L ${ }^{-1}$ ). Figure 4 presents summaries of Irgarol concentrations found in water bodies around the world and in Campos dos Goytacazes, this work. Figure 5 shows mass fragmentogram in SIM mode for atrazine (Figure 5A; $m / z, 200$ ) and Irgarol (Figure $5 \mathrm{~B} ; \mathrm{m} / \mathrm{z}, 182$ ) in river water samples from downtown of Campos dos Goytacazes and from standard compounds spiked at a final concentration of $0.20 \mu \mathrm{g} \mathrm{L}^{-1}$ in an unpolluted river water sample (Figures $5 \mathrm{D}$ and $5 \mathrm{E})$.

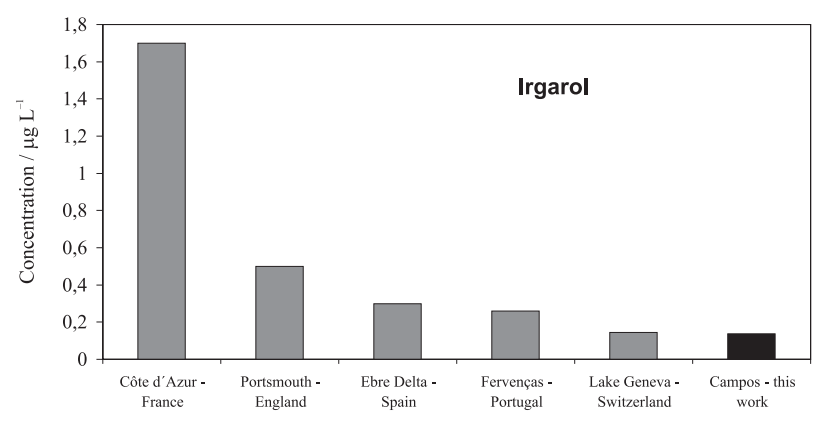

Figure 4. Reported values for Irgarol concentrations in water bodies $\left(\mu \mathrm{g} \mathrm{L}^{-1}\right)$ around the world and in this study.

\section{Polycyclic aromatic hydrocarbons}

Benzo[a]pyrene was detected only at $0.255 \mu \mathrm{g} \mathrm{L}^{-1}$ in Resende (July/2001), near the Presidente Dutra highway. This is illustrated in Figure 5C, while Figure 5F shows the $\mathrm{m} / \mathrm{z}, 252$ mass fragmentogram from the corresponding benzo[a]pyrene standard spiked at a final concentration of $0.20 \mu \mathrm{g} \mathrm{L}^{-1}$ in an unpolluted river water sample. PAHs were not detected in the water samples from Campos dos Goytacazes. In a previous work regarding PAHs in the Paraíba do Sul River, concentration values of benzo[a]pyrene were from $0.03 \mu \mathrm{g} \mathrm{L}^{-1}$ up to $1.2 \mu \mathrm{g} \mathrm{L}^{-1}$ near the CSN industry (National Siderurgical Company, the most important industry in this area with metallurgical activities), in the Volta Redonda city ${ }^{12}$ (see map).

The Brazilian regulations (CONAMA n ${ }^{\circ}$ 20/1986) specify that benzo[a]pyrene detection should not exceed $0.01 \mu \mathrm{g} \mathrm{L}^{-1}$ in drinking water, while Brazilian Health Ministry (regulation $\mathrm{n}^{\circ}$. 1469/2000) specify a value of $0.70 \mu \mathrm{g} \mathrm{L}^{-1}$. Lethal concentration $\left(\mathrm{LD}_{50}\right.$ ) down to less than $10 \mu \mathrm{g} \mathrm{L}^{-1}$ for total PAHs ( $\mathrm{PAHs}$ ) has been reported for various organisms and is used as a threshold value. ${ }^{13}$ Imperative and maximum admissible concentration of polycyclic aromatic hydrocarbons (total of 6 compounds; fluoranthene, benzo[b]fluoranthene, benzo[k]fluoranthene, benzo[a]pyrene, benzo[ghi]perylene and indeno[1,2,3cd]pyrene) in surface water for drinking water purposes is $0.2 \mu \mathrm{g} \mathrm{L}^{-1}$ in the EC regulations. ${ }^{1}$ 

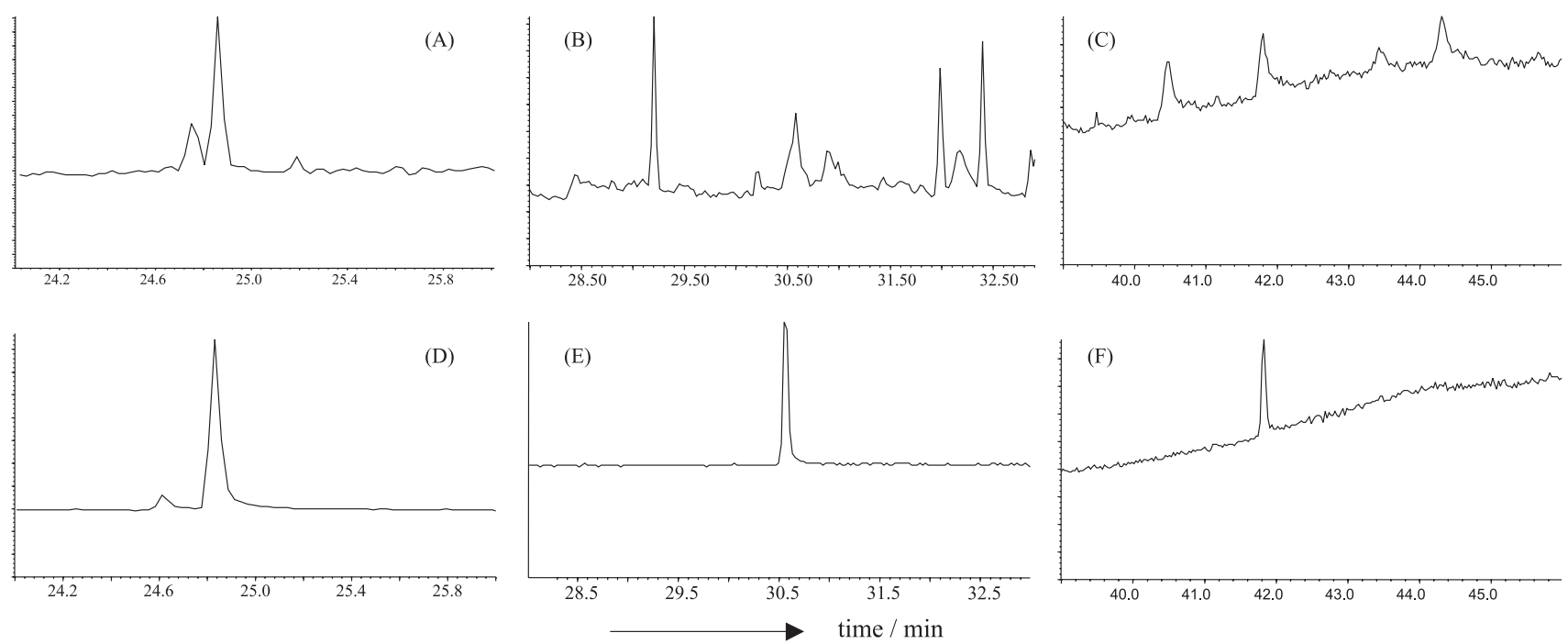

Figure 5. Paraíba do Sul River water samples: (A) $\mathrm{m} / \mathrm{z} 200$ mass fragmentogram, atrazine characteristic ion, from downtown of Campos dos Goytacazes (October/2001); (B) m/z 182 mass fragmentogram, Irgarol characteristic ion, from downtown of Campos dos Goytacazes (July/ 2001); (C) $\mathrm{m} / z, 252$ mass fragmentogram, benzo[a]pyrene characteristic ion, from Resende (July/2001); Unpolluted water sample spiked with $0.20 \mu \mathrm{g} \mathrm{L}^{-1}$ of each standard, after passing through the Oasis cartridges; (D) $\mathrm{m} / \mathrm{z} 200$ mass fragmentogram of Atrazine; (E) $\mathrm{m} / \mathrm{z} .182 \mathrm{mass}$ fragmentogram of Irgarol; (F) $\mathrm{m} / \mathrm{z} 252$ mass fragmentogram of Benzo[a]pyrene.

Total parent $\mathrm{PAH}$ concentrations $\left(\mathrm{ng} \mathrm{L}^{-1}\right)$ in sub-surface water from various marine sites in the world were: 0.300 $0.594 \mathrm{ng} \mathrm{L}^{-1}$ in the Baltic Sea, 4-36 ng L $\mathrm{L}^{-1}$ in Seine River and Estuary (France), 106-945 ng L${ }^{-1}$ in Western Xiamen Bay $^{14}$ (China), 4228-29325 ng L ${ }^{-1}$ in Daya Bay ${ }^{13}$ (China).

\section{Conclusion}

Precision, accuracy, linearity, specificity and limits of detection were determined for four pesticides and six polycyclic aromatic hydrocarbons investigated in this study using Oasis cartridge solid phase extraction followed by GC/MS analysis. This methodology was applied to real river water samples from the Paraíba do Sul in two distinct cities where the main pollution would be from industrial and agricultural activities. The detected compounds were atrazine and Irgarol (triazines pesticides) in downtown of Campos dos Goytacazes and benzo[a]pyrene in Resende. The detected concentration values were around $0.2 \mu \mathrm{g} \mathrm{L}^{-1}$.

Among the organic pollutants determined in this study, atrazine is caused by agricultural contamination, mainly from sugar-cane crops; Irgarol is used in boating paints and benzo[a]pyrene has an fossil fuel origin.

Although this analytical method were optimised and applied for analysing 75 organic compounds, mainly pesticides, halogenated compounds and phenols, in river water samples from Portugal in a previous paper, ${ }^{7}$ in the present one we extended the method to the detection of polycyclic aromatic hydrocarbons and applied for analysing Brazilian river water samples.

\section{Acknowledgements}

E. Gerchon acknowledges the grant from $\mathrm{CNPq}$ (PIBIC) and FAPERJ is acknowledged for financial support to this project (E-26/170.619/2001) and the grant to E.O. Reis (E-26/152.409/2000).

\section{References}

1. Hennion, M.-C.; Pichon, V.; Barceló, D.; Trends Anal. Chem. 1994, 13, 361

2. Barceló, D.; Hennion, M.-C.; Trace Determination of Pesticides and Their Degradation Products in Water, Elsevier: Amsterdam, 1997.

3. Barceló, D.; J. Chromatogr. 1993, 643, 117.

4. Greymore, M.; Stagnitt, F.; Allison, G.; Environ. Int. 2001, $26,483$.

5. Lakshminarayan, P.G.; Bouzaher, A.; Shogren, J.F.; J. Environ. Manage. 1996, 48, 111.

6. Zhou, J.L.; Hong, H.; Zhang, Z.; Maskaoui, K.; Chen, W.; Wat. Res. 2000, 34, 2132.

7. Azevedo, D.A.; Lacorte, S.; Vinhas, T.; Viana, P.; Barceló, D.; J. Chromatogr. A 2000, 879, 13; Azevedo, D.A.; Lacorte, S.; Viana, P.; Barceló, D.; J. Braz. Chem. Soc. 2001, 12, 532.

8. Tóth, S.; Becker van Slooten, K.; Spack, L.; de Alencastro, L. F.; Tarradellas, J.; J. Bull. Environ. Contam. Toxicol. 1996, 57, 426.

9. Ferrer, I.; Barceló, D.; J. Chromatogr. A 1999, 854, 197.

10. Tolosa, J.; Readman, J. W.; Blaevoet, A.; Ghilini, S.; Bartocci, J.; Gorvat, M.; Mar. Pollut. Bull. 1996, 32, 335. 
11. Gough, M. A.; Fothergill, J.; Hendrie, J. D.; Mar. Pollut. Bull. 1994, 28, 613.

12. COPPE/UFRJ. Programa Estadual de Investimentos da Bacia do Rio Paraíba do Sul - RJ. Análise Ambiental. MPO/SEPURB/ PQA-ABC-PNUD-UFRJ/COPPE. BRA/96/017 PROJECT, 1999. (www.hidro.ufrj.br).
13. Zhou, J.L.; Maskaoui, K.; Environ. Pollut. 2003, 121,269.

14. Maskaoui, K.; Zhou, J.L.; Hong, H.S.; Zhang, Z.L.; Environ. Pollut. 2002, 118, 108.

Received: February 19, 2003 Published on the web: March 30, 2004 